\title{
NOTES
}

\section{WHITMAN'S EARLIEST ATTEMPT TO ABSORB THE CIVIL WAR INTO LEAVES OF GRASS}

Whitman's decision to bind leftover pages of Drum-Taps and Sequel to DrumTaps into the first copies of the 1867 Leaves of Grass marks the poet's earliest move in print towards proclaiming, as he would in 1871, that "my Book and the War are one." But with Drum-Taps hastily appended to only the earliest copies of the fourth edition, the division between Whitman's "Book" and the "War" were still apparent in 1867, legible in the separate title page and discrete pagination for Drum-Taps within Leaves of Grass. However, this manuscript leaf held by Amherst College's Archives \& Special Collections suggests that Whitman may have begun toying with the idea of absorbing Drum-Taps within Leaves of Grass earlier than suspected, conceiving of a new volume, significantly reorganized to incorporate the war seamlessly, before the fourth edition was even printed. Thus, Whitman's odd choice to tack his Civil War poetry onto 1867 Leaves of Grass appears to have been motivated, not by any reticence to merge fully his book and the war, but by a simple pragmatic concern: finding a use for unbound copies of Drum-Taps. Much like the printing of Drum-Taps itself, Whitman's awkward incorporation of those poems into the 1867 edition was an exercise in frugality. It simply was cheaper for the poet to utilize his loose copies of Drum-Taps than it was to reorganize and expand Leaves of Grass.

In the manuscript pictured on the back cover, Whitman has written in blue pencil, "Drum-Taps / comes in here," under which he has noted in a different pencil, "(after page 404 / and before page 405)." Though we cannot date this manuscript precisely, the page numbers Whitman lists provide a major clue. These notations cannot refer to the 1867 edition, which contains only 338 pages. More likely, Whitman's note points to the third edition of Leaves of Grass published in 1860; it is conceivable that this manuscript page was once used as a place-holder in his personal "Blue Book" copy of the 1860 edition, where similar blue penciling appears.

By identifying the 1860 edition as the most plausible reference in this manuscript, we learn that Whitman may have imagined fully integrating his Civil War verse within Leaves of Grass as early as 1865, much earlier than the appended Drum-Taps of 1867 suggests. Whitman appears to be contemplating inserting Drum-Taps after the poem "Mannahatta" (LG 1860, 404-405) and before "France, The $18^{\text {th }}$ Year of These States" ( $\left.L G 1860,406-407\right)$. When the "Drum-Taps" cluster first appears in 1871, it "comes in" near the same spot Whitman flags in this manuscript, directly following "To the States" (LG 1860, 400-401) and "To a President" ( $L G$ 1860, 402). Although most former Drum-Taps poems appear earlier in the 1871 edition, several Civil War poems do appear between "Mannahatta" and "France, The $18^{\text {th }}$ Year of These States," including "Old Ireland," "Solid, Ironical, Rolling Orb," "Bathed in 
War's Perfume," "Song of the Banner at Day-Break," "Ethiopia Saluting the Colors," "Lo! Victress on the Peaks," "World, Take Good Notice," and "ThickSprinkled Bunting." Though Whitman would not characterize Leaves of Grass as "revolving" around "the strange sad war" until 1871, this manuscript offers some of the earliest evidence of his desire to have Leaves of Grass absorb the Civil War even before the poet's first experimentation in 1867.

The University of Iowa

ERIC CONRAD 